Meta

Journal des traducteurs

Translators' Journal

\title{
A Corpus-based Study of Spanish Translations of the Verb 'report' in Biomedical Research Articles
}

\section{Ian A. Williams}

Volume 54, numéro 1, janvier 2009

URI : https://id.erudit.org/iderudit/029798ar

DOI : https://doi.org/10.7202/029798ar

Aller au sommaire du numéro

Éditeur(s)

Les Presses de l'Université de Montréal

ISSN

0026-0452 (imprimé)

1492-1421 (numérique)

Découvrir la revue

Citer cet article

Williams, I. A. (2009). A Corpus-based Study of Spanish Translations of the Verb 'report' in Biomedical Research Articles. Meta, 54(1), 146-160.

https://doi.org/10.7202/029798ar

\section{Résumé de l'article}

Le présent article fait état d'une étude empirique des traductions du verbe anglais 'report' en espagnol. L'étude a été effectuée à partir d'un vaste corpus d'articles de recherche médicale. Une analyse quantitative révèle des différences significatives entre les choix lexicaux des traducteurs et les choix d'auteurs espagnols écrivant dans leur langue maternelle. L'analyse contextuelle montre que le verbe est employé dans trois cadres fondamentaux, à savoir le cadre institutionnel, le cadre de la communauté et du malade, et celui de la recherche. Dans le dernier cas, il peut s'agir de l'étude clinique présentée dans l'article analysé, des recherches antérieures de ses auteurs, ou des travaux publiés par d'autres auteurs. La prise en compte de facteurs linguistiques tels que les collocations, la structure de la phrase et les caractères spécifiques de la situation communicative, permet de faire des choix lexicaux appropriés afin de traduire les différents usages de 'report', un verbe anglais polysémique. 


\title{
TERMINOLOGIE ET LINGUISTIQUE
}

\section{A Corpus-based Study of Spanish Translations of the Verb 'report' in Biomedical Research Articles}

\author{
IAN A. WILLIAMS \\ Universidad de Cantabria, Santander, Spain \\ williams@unican.es
}

\begin{abstract}
RÉSUMÉ
Le présent article fait état d'une étude empirique des traductions du verbe anglais 'report' en espagnol. L'étude a été effectuée à partir d'un vaste corpus d'articles de recherche médicale. Une analyse quantitative révèle des différences significatives entre les choix lexicaux des traducteurs et les choix d'auteurs espagnols écrivant dans leur langue maternelle. L'analyse contextuelle montre que le verbe est employé dans trois cadres fondamentaux, à savoir le cadre institutionnel, le cadre de la communauté et du malade, et celui de la recherche. Dans le dernier cas, il peut s'agir de l'étude clinique présentée dans l'article analysé, des recherches antérieures de ses auteurs, ou des travaux publiés par d'autres auteurs. La prise en compte de facteurs linguistiques tels que les collocations, la structure de la phrase et les caractères spécifiques de la situation communicative, permet de faire des choix lexicaux appropriés afin de traduire les différents usages de 'report', un verbe anglais polysémique.
\end{abstract}

\begin{abstract}
This paper describes an empirical contextual study of the Spanish verbs that translate 'report' carried out on an extensive corpus of medical research articles. A quantitative analysis revealed significant differences between the lexical choices made by the translators and those made by native Spanish authors. The contextual analysis showed that reporting occurs in three basic settings, namely, the institutional setting, the community and patient setting, and the research setting. In the latter, research referred to the current study (i.e., the new clinical study presented in the article), to previous research by the same authors, or to other authors' published work. Within these contexts, consideration of linguistic factors such as collocation, sentence structure and specific features of the communicative situation allows the translator to make the appropriate lexical choices for the wide range of uses of the polysemous English verb 'report.'
\end{abstract}

\section{MOTS-CLÉS/KEYWORDS}

medical translation, English-Spanish, corpus-based studies, quantitative analysis, contextual analysis

\section{Introduction}

In biomedical research articles (RAs), the verb 'report' presents translation difficulties for a number of reasons. It is polysemous in that it corresponds to a variety of communicative situations in medical and research settings. It is extremely versatile collocationally since what is reported can be virtually any concept describable, ani- 
mate or inanimate, concrete or abstract. And, syntactically, it is associated with a wide range of structures that include a simple noun or noun phrase, a prepositional complement with on or about, a noun clause introduced by that, and, like many other cognitive or reporting verbs, an infinitive structure ( $\mathrm{X}$ is reported to + infinitive), which is not always easy to render in Spanish.

This enormous pragmatic, collocational and syntactic versatility makes 'report' one of the most frequent lexical verbs in medical RAs. ${ }^{1}$ Another important aspect to consider is that the discourse of these articles is characterized by objectivity and impersonal tone. In this regard, 'report' also fits in perfectly in two ways. First, in citations of other researchers' work, the citing author does not pass judgement, since the neutrality of 'report' simply states that the reference exists in black and white. Secondly, in terms of transitivity, 'report' is a verbal process, so that the basic structure will have at most three participants: sayer + process + verbalization + receiver (Halliday 1985: 129-130). However, the receiver of the message appears only very rarely in RAs. The participant role sayer not only covers animate nouns (named researchers, authors, patients, etc.) but is often extended to include anything that emits a message, e.g., articles, studies, or clinical trials. In addition, sayer is frequently suppressed by using the passive, thus reducing the structure to two basic components: 'report' and the nominal expressing the verbalization. While this depersonalization suits the author's needs, it may create further problems for the translator, since ambiguity can arise as to who exactly is reporting in the communicative situation.

In translating 'report' into Spanish in RAs, there is no single verb that will cover the multitude of situational and linguistic contexts. Navarro (2000: 435) offers useful advice but no empirical studies have investigated the contextual use of 'report' and its translation equivalents in Spanish. This paper describes a contextual analysis of these lexical items performed on an extensive corpus of medical RAs. Section 2 outlines the methodology used. In section 3, the main quantitative results are presented and, in section 4 , the various communicative situations are analyzed and the translation potential of Spanish verbs is discussed in context.

\section{Methods}

The study was performed on a computerized corpus of 192 RAs (almost 500,000 words of running text) divided into three subcorpora: 64 English source texts (157,650 words), their 64 Spanish translations (185,000 words), and a comparable subcorpus of 64 Spanish native RAs (140,250 words) (for details, see Williams 2006). All instances of the verb 'report' were located with the concordancing program of Wordsmith Tools (Scott 1997). The translations of these instances were then found, classified and quantified. Finally, the Spanish comparable texts were searched, and the data obtained were compared with the translation data both quantitatively and qualitatively in the contextual study.

Since the Spanish equivalents of 'report' also translate other verbs, the total frequencies were calculated for the verbs used twice or more for 'report' and for other verbs within the semantic scope of 'report' used only once in the translations. Where possible, these figures were compared with the corresponding frequencies in the Spanish native texts by means of a binomial test. The data are shown in Table 1. 


\section{Results}

For the 210 instances of 'report' found in the English source texts (see Table 1), the translators used a total of 27 different verbs, plus the technique of verb-noun transposition (7 instances), or the verb was not translated (16 instances). The left-hand column shows that the most frequent choices were comunicar (35) and describir (33), with six verbs having frequencies between 10 and 20, and five verbs appearing between twice and nine times. A further 14 verbs were used only once.

TAble 1

Spanish translations of the verb 'report' and a comparison of the most frequent verbs involved between the translated texts (Tr) and Spanish native texts (Sp)

\begin{tabular}{|c|c|c|c|c|}
\hline & \multirow{2}{*}{$\begin{array}{l}\text { No. instances } \\
\text { for 'report' }\end{array}$} & \multicolumn{3}{|c|}{ Total instances } \\
\hline & & $\operatorname{Tr}$ & $\mathrm{Sp}$ & $P$ value \\
\hline Comunicar & 35 & 42 & 17 & $<0.05$ \\
\hline Describir & 33 & 136 & 93 & n.s. \\
\hline Publicar & 18 & 56 & 50 & n.s. \\
\hline Referir & 15 & 29 & 45 & $<0.01$ \\
\hline Documentar & 14 & 37 & 3 & $<0.001$ \\
\hline Observar & 14 & 358 & 161 & $<0.001$ \\
\hline Informar & 12 & 46 & 5 & $<0.001$ \\
\hline Encontrar & 10 & 135 & 223 & $<0.001$ \\
\hline Mencionar & 8 & 26 & 5 & $<0.01$ \\
\hline Presentar & 6 & 344 & 302 & $<0.05$ \\
\hline Notificar & 4 & 7 & 0 & n.a. \\
\hline Afirmar & 2 & 18 & 10 & n.s. \\
\hline Indicar & 2 & 96 & 62 & n.s. \\
\hline Analizar & 1 & ---- & ---- & \\
\hline Calcular & 1 & ---- & --- & \\
\hline Comentar & 1 & 7 & 8 & n.s. \\
\hline Concluir & 1 & ---- & ---- & \\
\hline Decir & 1 & 1 & 1 & n.a. \\
\hline Demostrar & 1 & ---- & ---- & \\
\hline Estudiar & 1 & ---- & ---- & \\
\hline Manifestar & 1 & 17 & 6 & n.s. \\
\hline Mostrar & 1 & ---- & ---- & \\
\hline Notar & 1 & ---- & ---- & \\
\hline Realizar & 1 & ---- & ---- & \\
\hline Recordar & 1 & ---- & ---- & \\
\hline Reseñar & 1 & 2 & 6 & n.a. \\
\hline Señalar & 1 & 10 & 46 & $<0.001$ \\
\hline Zero translation & 16 & ---- & ---- & \\
\hline Noun transposition & 7 & --- & ---- & \\
\hline Total & 210 & 1367 & 1043 & n.s. \\
\hline
\end{tabular}

n.s. = not statistically significant; n.a. = not applicable

The statistical analysis showed no significant differences for the total number of appearances of describir, publicar, afirmar, indicar, comentar, and manifestar, so that translating 'report' by these verbs had no effect on their overall distribution. This is particularly important for describir and publicar, since they accounted for about 25\% of the translations of 'report.' 
Excesses in the translated texts were observed for comunicar, documentar, observar, informar and mencionar. These results suggest that the contexts in which they appear in the translations may not be appropriate. Interestingly, informar, which is suggested as a frequent option (Navarro 2000: 435), only appeared five times in the Spanish native texts, four times for doctors informing patients about the experimental nature of a treatment, and only once in a context suitable for 'report.' In the translations, 20 of the 46 instances of informar were in the set phrase consentimiento informado, but exclusion of these still leaves an overrepresentation of this verb. Spanish translators also overuse observar so that this verb should be avoided as an option for 'report' despite its neutral tone (Williams 2007).

In contrast, deficits were evident in the translations for referir, encontrar, señalar and presentar, although this last verb was only slightly underrepresented. These results suggest that many of the excesses noted above could be resolved by resorting to these verbs in the appropriate contexts. Curiously, encontrar suffers a fate opposite to that of observar in the hands of translators. Owing to its neutral tone, it can be used for 'report,' but it should be remembered that it is not a true reporting verb, and other options may be possible.

\section{Contextual analysis}

The communicative contexts reflected in the 210 instances of 'report' in the English subcorpus can be broadly grouped into three types. (1) Institutional setting: a member of the medical profession notifies an authorized body (e.g., a medical registry) or informs a colleague - doctor or researcher - officially or as part of a protocol. These communicative acts form part of the data collection and documentation stage prior to publication. (2) Community and patient setting: a member of the general population or a patient (sometimes a parent in a pediatric setting) in a patient-doctor relationship provides data via questionnaire, interview, medical history, follow-up visits, etc., again as part of the data collection process. (3) Research setting: the reporting forms part of the publication process and can refer to various situations within this expert-to-expert communication: 'report' relates to the current study (i.e., the new clinical study), to previous research by the same authors (current authors), and to published work by other researchers. The distribution of the occurrences in the three main settings and for the three research subsettings is shown in Figure 1.

FIGURE 1

Distribution of the 210 instances of 'report' in the English research articles by main setting and subsetting

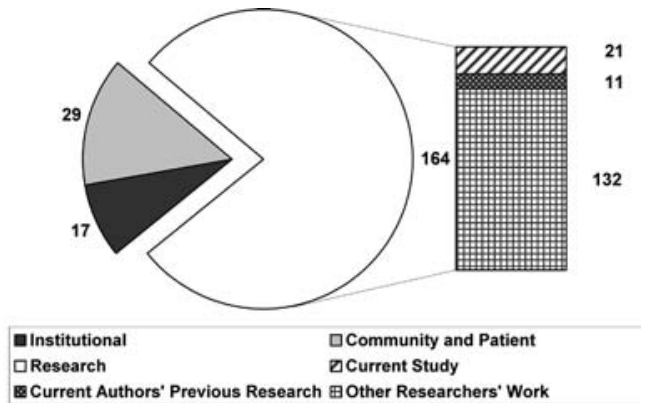




\subsection{Institutional setting}

Of the verbs used by translators in these contexts, informar appeared five times, notificar on four occasions, and documentar once; verb-noun transposition was used four times and three instances of 'report' were not translated. In one large clinical trial, the instances of notificar expressed the reporting of adverse events, including fatal events, to the central committee. In another trial, documentar appeared in a similar context. This verb, however, stresses the recording rather than the communication of information, so that notificar represents a better choice: ${ }^{2}$

(1) For cardiovascular events, deaths rather than non-fatal events are used since non-fatal events were less reliably reported once patients had been lost to follow up.

$>$ Para los acontecimientos cardiovasculares, se utilizan las muertes antes que los acontecimientos no fatales, dado que los acontecimientos no fatales fueron documentados de una manera menos fidedigna una vez que los pacientes habían sido perdidos para el seguimiento.

* Para los acontecimientos cardiovasculares, se utilizan las muertes y no los episodios no mortales, ya que éstos se notificaron de forma menos fiable en el caso de pacientes ya perdidos para el seguimiento.

Four instances of informar plus a transposition to información occurred in a study on risk factors for small-for-gestational-age births. In this setting, the author commented on the different requirements for reporting births and fetal deaths to the relevant authorities in the two countries involved. The meaning of informar is too general to describe this context adequately; the Spanish verbs used in this setting are notificar and declarar, plus their nominalizations: ${ }^{3}$

(2) In Norway, all products of conception of 16 or more weeks of gestational age are to be reported. In Sweden, although all live births are to be reported, only fetal deaths of 28 weeks or more gestational age are to be reported.

$>$ En Noruega, todos los productos de la concepción de 16 o más semanas de edad gestacional deben ser informados. En Suecia, aunque deben ser informados todos los nacidos vivos, sólo deben informarse las muertes fetales de edad gestacional de 28 semanas o más.

* En Noruega, es de declaración obligatoria todo producto de 16 semanas o más de gestación En Suecia, aunque deben notificarse todos los nacimientos vivos, sólo deben declararse las muertes fetales de 28 semanas o más de gestación.

When data are reported, there may be a tendency to overreport or underreport certain events or phenomena, which can distort the results of a study. The term for this, 'reporting bias,' occurred twice and was rendered as errores de publicación in one text and as sesgo de informar in the second. As both contexts concerned data collection, the equivalent Spanish term is sesgo de notificación. ${ }^{4}$

Two identical cases of transposition occurred in a study in which exclusion of certain diseases was based on the radiologist's report, so that 'as reported by the radiologist' became según el informe del radiólogo, which is a neat way of dealing with this type of interdepartmental report.

The three cases when 'report' was not translated involved ambiguity, as in [3]

(3) Review of complications of angioplasty reported within the 1 st $24 \mathrm{~h}$ of the procedure revealed that more patients with than without antecedent angina had reocclusion of the infarct-related artery or reinfarction. 
$>$ Una revisión de las complicaciones de la angioplastia s durante las primeras 24 horas del procedimiento reveló que una mayor proporción de pacientes con angina previa que sin ella presentaban una reoclusión de la arteria relacionada con el infarto o un reinfarto.

In [3], it is not clear whether the reporting was done by the patient or officially by the participating doctor within the study protocol. The translator has chosen not to render 'reported,' but another solution might be to retain the ambiguity by selecting verbs like referidas or señaladas, which occur in both settings, or registradas or ocurridas, which focus on the recording and the event itself.

\subsection{Community and patient setting}

The most frequent verbs used by the translators in this context were referir (6 times), mencionar (4), documentar (3), afirmar (2), and comunicar (2). Seven verbs (decir, manifestar, observar, presentar, notar, recordar, señalar) occurred once each. One noun transposition (comunicación) was made, and no translation given for 'report' on four occasions. In contrast, of 23 similar contexts identified in the Spanish native texts, almost half (11) corresponded to referir, followed by afirmar (3), admitir (2), declarar (2), with indicar, negar, reconocer, relatar and señalar each appearing once.

As suggested above, all the situations involving mencionar and documentar could be expressed by referir:

(4) All but one of the men reported having regularly lifted weights of over $25 \mathrm{~kg}$.

$>$ Todos, excepto un individuo, mencionaron haber cargado de una manera regular pesos de más de $25 \mathrm{~kg}$.

* Todos, excepto un individuo, referían haber cargado con frecuencia pesos de más de $25 \mathrm{~kg}$.

(5) Mild dizziness was reported by six patients in each group.

$>$ En cada grupo, seis pacientes documentaron un mareo leve.

* Seis pacientes de cada grupo refirieron mareo leve.

The same is true of the cases of decir, notar, and presentar. The first corresponded to reporting by questionnaire and, in the others, the translator has focussed on the manifestation and experiencing, rather than the reporting, of symptoms. The alternative version exploits coordination and ellipsis to avoid repeating the verb:

(6) Six patients reported mild pain that resolved within the first postoperative week. One patient reported a transient foreign-body sensation.

$>$ Seis pacientes presentaron un dolor leve que desapareció dentro de la primera semana postoperatoria. Un paciente notó una sensación transitoria de cuerpo extraño.

* Seis pacientes refirieron un dolor leve que se resolvió dentro de la primera semana postoperatoria y otro, una sensación transitoria de cuerpo extraño.

The instance of observar in dolor de cadera según lo observado en el cuestionario inicial ('hip pain as reported on the initial questionnaire') is better rendered by según lo indicado/ señalado [...], which reflect the communicative aspect and express the neutral tone.

The contexts in which comunicar and its nominalized form appeared related to parents reporting about their children, as in [7]. No parallel examples occurred in the Spanish texts, so that comunicar may be acceptable. But, when the phenomenon 
reported (complications) was taken as a guide, it was seen to collocate with señalar in the Spanish subcorpus.

(7) No complications from the procedure were reported.

$>$ No hubo comunicación de complicación alguna.

* No se señaló ninguna complicación relacionada con la técnica.

The use of manifestar for questionnaire reporting seems appropriate, but afirmar or declarar also fitted the context. The instance of recordar was due to recasting by the translator to achieve a more acceptable version:

(8) In $97 \%$ of the cases, mothers had recalled the birth weights of previous infants to within 50 grams. The exact birth weight was reported by $89 \%$ of the mothers.

$>$ En el 97\% de los casos las madres habían recordado los pesos de sus hijos con diferencias de $50 \mathrm{~g}$. El 89\% de las madres recordaron el peso exacto.

Of the omissions, referir and declarar were indicated in two contexts related to questionnaire reporting, one mention 'Birthweights reported by the mothers' was redundant and better expressed as the demonstrative in Estos pesos. The final case, shown in [9], involved ambiguity that makes it difficult to find a neat solution with a reporting verb:

(9) Vaginal symptoms such as dryness and discomfort seem to be most often reported five to six years after menopause. ${ }^{6}$

$>$ Los síntomas vaginales como sequedad y otras molestias parecen ser más frecuentes cinco o seis años después de la menopausia. ${ }^{6}$

Either patients or researchers could be reporting in this context. Parecen referirse con mayor frecuencia retains the ambiguity as it covers both settings, but omission seems justified here.

\subsection{Research setting}

\subsubsection{Current study}

For the current study, the most frequent verb in the translations was comunicar (8 times), followed by presentar (4), describir (3), with comentar, documentar, estudiar, indicar, mencionar appearing once, and one instance not translated. However, use of comunicar was not attested in the Spanish texts, where presentar (8) was the preferred choice, with describir (5), aportar (3), comentar (2), exponer (2), and indicar (1) also used in similar contexts.

About half the cases appeared in the Introduction section to present the new research by stating the aim or by giving a brief description of the study (Swales 1990; Williams 2001).

(10) The primary objective of this paper is to report our experience with the use of surfactant therapy in a case series of 49 full-term infants with respiratory failure due to RDS and MAS.

$>$ El objetivo principal del presente artículo es comunicar nuestra experiencia sobre el empleo del tratamiento con surfactante en una serie de 49 casos de recién nacidos a término con insuficiencia respiratoria debida al SDR y al SAM. 
(11) We report 20 cases of pemphigus foliaceus, all of them involving young women seen from November 1985 through January 1987 in Sousse, Tunisia.

> Comunicamos 20 casos de pénfigo foliáceo, todos ellos en mujeres jóvenes examinadas entre noviembre de 1985 y enero de 1987 en Sousse (Túnez).

In view of the reluctance of Spanish writers to use comunicar in these contexts, aportar or exponer were seen to collocate with experiencia and are appropriate choices in [10], whereas either presentamos or describimos are suitable with casos in [11].

Elsewhere in the RA, usually in the Discussion, reference is contrastive or metatextual, so that the reader can readily identify the data to be commented on. Occasionally, 'report' refers the reader to a table and, although describir is used for this purpose, the most frequent verbs are exponer, recoger and mostrar. For reference to other parts of the RA, both describir and mencionar are appropriate, but close examination of the text can lead to more descriptive options, as in 'one case of portal vein thrombosis reported above,' which was aptly translated as un caso, ya comentado, de trombosis de la vena porta. However, this type of reference in English RAs is often the result of the impersonal style: the first-person is avoided because repetition of the obligatory subject pronoun 'we' is considered obtrusive, drawing too much attention onto the authors. This, in turn, affects the frequency of the possessive pronoun 'our.' First-person reference in Spanish occurs in the verb ending, is less obtrusive and, together with associated forms, acts as a useful cohesive device (Williams 1994: 153). If this is exploited textually, it can make verbal references redundant, with Los hallazgos comunicados en este estudio ('The findings reported in this paper') more simply expressed as Nuestros resultados. It can also avoid unfortunate collocations, as in en el $42 \%$ de los pacientes comunicados en este estudio ('in $42 \%$ of the patients reported here'), which can be rendered by en el $42 \%$ de nuestros pacientes. However, recourse to verbs beyond the scope of reporting may be required, so that los errores comunicados en el presente estudio ('the errors reported in this study') is better expressed as los errores [de medición] constatados en este estudio.

\subsubsection{Current authors' previous research}

The picture is very similar for self-citation. The verbs used by the translators were describir (5) and comunicar (4) with presentar and publicar each appearing once. Spanish authors preferred describir (4), publicar (3) and recoger (1), but in some contexts the notion of reporting was expressed by a noun (trabajo, estudio, artículo, publicación) in an adjunct followed by a verb of observation (encontrar, detectar, comprobar, etc.). The reluctance to use comunicar for self-reporting suggests that this verb should be avoided in this setting.

(12) We have previously reported 12 that intraoperative echocardiography after valve repair for mitral regurgitation can detect failed valve repair, permitting further surgical treatment during the same thoracotomy.

$>$ Hemos comunicado previamente12 que la ecocardiografía intraoperatoria tras la reparación de la válvula por insuficiencia mitral puede detectar una reparación defectuosa, permitiendo tratamiento quirúrgico adicional durante la misma toracotomía.

The reporting frame in [12] could be En un trabajo anterior12 señalamos que [...] as señalar lies in the semantic scope of 'report' and combines well with reported comments as opposed to reported results. 
As mentioned in the Introduction, the use of 'report' in depersonalized settings can give rise to ambiguity. In [13], the depersonalized self-citation, in which the identity of the authors lies hidden behind the passive and superindex number, leads on to the presentation of the current study in the third sentence.

(13) The results of a selective policy of excision based on clinical assessment of tumour thickness using margins of 1,2 and $3 \mathrm{~cm}$ for tumour groups of increasing thickness were reported $^{11}$ in 1985 . It was demonstrated that, in terms of recurrence, the maximum excision margin necessary to achieve local control could confidently be reduced to $3 \mathrm{~cm}$ in melanoma $>1.50 \mathrm{~mm}$ thick and that tumour thickness could be estimated accurately by preoperative clinical assessment. The effect of a further reduction in the maximum width of excision to $2 \mathrm{~cm}$ is presented.

$>$ En 1985 se comunicaron los resultados de un protocolo selectivo de la escisión, basándose en la valoración clínica del espesor del tumor, utilizando márgenes de 1,2 y $3 \mathrm{~cm}$ para los grupos de tumores de grosor progresivamente creciente ${ }^{11}$. Se demostró que, en términos de recidiva, el margen máximo de escisión necesario para conseguir el control local podía reducirse de forma fiable a $3 \mathrm{~cm}$ para los melanomas $>1,50 \mathrm{~mm}$ de espesor y que el espesor del tumor podía ser calculado de forma segura mediante la valoración clínica preoperatoria. En este estudio se presenta el resultado de una mayor reducción, a $2 \mathrm{~cm}$, en la amplitud máxima de la escisión.

The translator has adjusted the syntax in the first and third sentences, but in Spanish the impersonal tone conveyed by the reflexive passive and past definite tense gives the impression of remoteness, so that the citation does not appear sufficiently relevant to motivate the new study. In fact, the two studies form part of the same research program. The introduction of the first person in a cohesive chain within a reporting frame, as indicated below, would serve to correct this impression:

* En 1985, nuestro grupo de trabajo publicó los resultados [...]

Demostramos que [...]

En este estudio presentamos [...]

\subsubsection{Other researchers' work}

The translation of 'report' referring to other researchers' work depends on the lexical and syntactic environment. The contextual analysis identified six environments: finite and non-finite 'as' clauses; infinitive constructions; preposed and postposed adjectival function; metonymy, in which a research noun replaces the researcher; passive sentences with a nuclear structure consisting only of 'report' plus reported concept; and contexts involving a researcher agent. The distribution of the 132 instances into these environments is shown in Figure 2.

Finite and non-finite 'as' clauses (e.g., as has been reported previously/ in other studies/ by other authors) are formulaic expressions and should be translated by equivalent formulae in Spanish. In the Spanish texts, these involved señalar, referir, reseñar, and the non-reporting verbs suceder and ocurrir. Thus, según se informó en otros estudios is better rendered by como ha sido señalado en otros estudios/ por otros autores. Spanish tends to prefer the personalized forms, and it is sometimes suitable to recover the named researcher: thus, como ya se comunicó anteriormente ${ }^{8}$ could become tal y como ha señalado $\underline{A n d o}^{8}$ ('as has been reported by $\mathrm{Ando}^{8^{\prime}}$ ). 
FIGURE 2

Distribution of the 132 instances of 'report' for other authors' research by lexical and syntactic environment

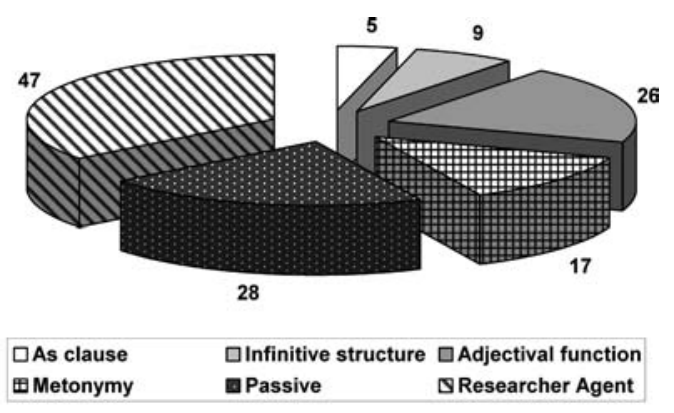

English infinitive structures will usually require translation by a sentence-initial reporting verb in the reflexive passive, although other reformulations are possible. For the 9 instances in the corpus, the translators used the reflexive passive ( 3 times), other reformulations with a reporting verb (3), and three instances were left untranslated. In [14] all that is required is the addition of the reporting frame (in curly brackets) to the proposition:

(14) Lung volume in infants has been reported to decrease even further during apneic pauses $^{13}$ and during rapid eye movement sleep. ${ }^{14}$

$>$ \{Se ha señalado que $\}$ el volumen pulmonar del lactante disminuye aún más durante las pausas apneicas ${ }^{13} y$ durante el sueño REM ${ }^{14}$.

If the reporting frame is followed by a noun clause, typical neutral tone verbs are señalar, indicar, describir and referir. If a complex nominal subject follows, describir, comunicar, and referir are indicated. In Spanish RAs, the discoursal role played by these sentence-initial verbs is important since they orient the reader by indicating the rhetorical status of the message introduced (Williams 2004: 85).

Far more numerous were the contexts with 'report' as a preposed (14 instances) or postposed (12) adjective. Of these, 18 were translated appropriately by publicar (7 instances), describir (6), comunicar (3), referir (1), and calcular (1). This last case involved the reported confidence interval in a published study, and the shift to the methodological verb was justified because the reporting context was clear.

Choice of verbs in these settings depends on collocation: publicar with casos, series, estudios, resultados and numerical concepts e.g., valores, frecuencias; describir can also go with abstractions, e.g., asociación, efecto, control; comunicar and referir are variants when values and some abstractions are involved. Less satisfactory combinations involved observar ( 2 instances with casos) and encontrar (3). Adjectival use of these verbs is far more common to refer to the current study, and so publicados is more appropriate than observados in [15]:

(15) Figure 3 shows the cumulative frequency of reported cases of second brain tumours. $>$ La figura 3 muestra la frecuencia acumulada de casos observados de tumores cerebrales secundarios.

Where encontrar occurred, more appropriate choices would have been comunicar or referir, as well as publicar. In the three instances where 'report' was not translated, 
reporting verbs were indicated in two cases, but for the third, shown in example [16], it is necessary to go beyond reporting verbs and insert reconocida ('recognized') in front of morbilidad asociada:

(16) [...] the possible circumvention of ECMO seems desirable in view of the reported associated morbidity of $25 \%$ to $40 \%$ of ECMO survivors. ${ }^{31}$

$>$ [...] parece deseable la posibilidad de eludir la ECMO en vista de la s morbilidad asociada del 25-40\% entre los supervivientes a esta técnica ${ }^{31}$.

A further 17 contexts involved what I call "anthropomorphic metonymy," in which the research replaces the researcher as sayer in an active verbal process. The collocational restrictions in this type of structure are far greater in Spanish than in English: estudios as subject can take demostrar, confirmar, poner de manifiesto, revelar, encontrar, referir, indicar and sugerir as reporting verbs. However, of these, only encontrar (2 instances), referir (1) and indicar (1) fall within the neutral scope of 'report,' and such cases are extremely rare. Nevertheless, translators tend towards too literal translations, where other strategies are required:

(1) adjunct with research noun + reporting verb:

(17) Several studies ${ }^{6-12}$ report that antecedent angina predicts a worse outcome in patients with myocardial infarction.

$>$ Varios estudios $^{6-12}$ concluyen que la angina previa predice una evolución peor en los pacientes con infarto de miocardio.

${ }^{*} \underline{\text { En diversos estudios }}^{6-12}$ se ha señalado que [...]

Within the range of options, señalar is a good choice, since it often takes a reported clause and combines well with reported comments or deductions as in [17]. Strategy

(4) (see below) could also be used here: Diversos autores han señalado que [...].

(2) adjunct with research noun + non-reporting verb, usually observational:

(18) The SHEP trial did not report any excess deaths from cancer in the active treatment group.

$>$ El ensayo SHEP no documentó ningún exceso de muertes por cáncer en el grupo de tratamiento activo.

* En el ensayo SHEP, no se halló ningún exceso de muertes por cáncer en el grupo de tratamiento activo.

For this strategy, the observational verbs maintain the neutral tone and the notion of reporting is transferred to the research noun in the adjunct. Typical verbs are encontrar, hallar, comprobar, constatar, as well as observar, which tends to be overused by translators.

(3) adjunct with research noun + statement of result:

(19) Another study12 of coronary angioplasty in cardiogenic shock reported a $27 \%$ hospital mortality rate among patients with a successful procedure.

$>$ Otro estudio12 sobre angioplastia coronaria en el shock cardiogénico mostró una tasa de mortalidad intrahospitalaria del $27 \%$ en los pacientes con buen resultado del procedimiento.

* En otro estudio12 sobre angioplastia coronaria en el choque cardiógeno, la mortalidad intrahospitalaria fue del $27 \%$ en los pacientes en los que la técnica se realizó con éxito. 
In [19] the force of mostrar (literally 'show') extends beyond the neutrality of 'report' implying acceptance on the part of the citing author (Williams 2008). This can have repercussions on the discourse and should, therefore, be avoided. The alternative has only a reporting frame and a factual statement of result in the past tense.

(4) change research word to autores / investigadores:

(20) Other series have reported much lower figures for the metastatic rate of SCC in organ graft recipients. ${ }^{3,8-12}$

$>$ Otros autores han comunicado tasas muy inferiores de SCC metastásicos en pacientes trasplantados ${ }^{3,8-12}$.

Estudios was appropriate as subject of encontrar and indicar in two contexts and artículos, as subject of comunicar in another. The remaining 14 contexts required recasting with one of the above strategies, but only two were in fact used by the original translators: strategy (1) on two occasions and strategy (4), as shown in [20].

There were 28 contexts in which passive structures were reduced to 'report' and the phenomenon reported, plus associated circumstances. In Spanish, these contexts typically require the reflexive passive, usually with a postposed subject. In fact, the Se reflexive form was used on 24 occasions, with a postposed subject in 21 cases. In the other four instances there were two true passives with ser + participle, one case of estar + participle, and one noun transposition was used. While the translators dealt appropriately with the syntactic aspect, their lexical choices were not always consistent with those in the Spanish native texts. The verbs selected in these contexts were publicar (5), documentar (5), describir (4), comunicar (4), mencionar (3), referir (2), with informar, observar, reseñar, and realizar each appearing once, the remaining case being the transposition.

As we have seen, documentar, mencionar and informar are not selected by Spanish authors, while observar and realizar involve a change in viewpoint from reporting to observation and performance of the research. As with the adjectival forms, the best guide to lexical choice is collocation between verb and associated concept. Estudios, ensayos and resultados collocate with publicar; casos with publicar, describir or recoger (in the literature); symptoms (dolor, uveitis) with referir or describir; abstractions like ausencia with señalar; finally describir is most often used in negative contexts and first time descriptions.

Nevertheless, for passive structures, apart from appropriate syntactic and lexical choice, attention should also be paid to the discourse. It may be suitable to introduce the occasional named researcher from the references to avoid an excessively impersonal style.

(21) In patients with serious arrhythmias, focal symptoms were reported in only 4 of 290 patients. ${ }^{20}$

$>$ En pacientes con arritmias graves, se describieron síntomas focales en tan sólo cuatro de 290 casos $^{20}$.

* En el trabajo de Rai20, sobre pacientes con arritmias graves, tan sólo cuatro de 290 enfermos presentaron sintomas focales.

In [21] the reporting frame with trabajo and the named researcher clearly indicate to the reader that the result that follows is a citation and not from the current study. Since the citation has a supportive function in the discourse, there should be no objection to the inclusion of the cited author's name. 
The final environment is the one in which the animate sayer is included. Named researchers appeared in 45 contexts, 36 active and 9 passive, and general researcher nouns, 'authors' and 'investigators,' in two active instances. The verbs used for 'report' in the translations were describir (11), observar (10), comunicar (6), publicar (4), referir (4), encontrar (3), informar (3), analizar, documentar and indicar (once each), while three passive instances were not translated. Of these verbs, observar and encontrar, because of their other functions, should be avoided as translations of 'report'; informar is not a normal choice of Spanish writers, and analizar involves a change of viewpoint.

From Table 1 it is clear that señalar, referir are underused by translators and the same is probably true for comunicar for this function. An advantage of switching to these communicative verbs is that they can be used in the present tense, as opposed to observational verbs, where the past is normal. This underlines the relevance of the citations to the current research, either to motivate the study in the Introduction or to contextualize the significance of the findings in the Discussion. Use of the present tense also makes the prose lighter. In addition, when several citations occur in close proximity, it is advisable to vary the syntactic structure, as seen above with the metonymies, by using other strategies. The named researcher can be placed in an adjunct attached to a research noun:

(22) Koster $^{26}$ reported, in her Danish study, that the most common reasons for abandoning treatment were: No effect (28\%), side effects (44\%), negative attitude (12\%) and symptoms relieved (9\%).

$>$ En su estudio realizado en Dinamarca, Koster $^{26}$ describió que las razones dadas por las mujeres para abandonar el tratamiento eran: ausencia de efecto (28\%), efectos secundarios (44\%), actitud negativa (12\%) y alivio de los sintomas (9\%).

* En el estudio realizado por Koster en Dinamarca ${ }^{26}$, los motivos más frecuentes de abandono del tratamiento eran: ausencia de efecto (28\%), efectos adversos (44\%), actitud negativa (12\%) y alivio de los sintomas (9\%).

Alternatively, the researcher can appear alone in an adjunct with para or según:

(23) Gartry and colleagues ${ }^{8}$ reported that the most marked anterior stromal haze occurred in those patients undergoing deeper ablations.

$>$ Gartry et al ${ }^{8}$ informaron que la opacidad estromal anterior más importante aparece en aquellos pacientes que han sufrido ablaciones más profundas.

* Para Gartry y cols ${ }^{8}$, la opacidad estromal anterior más importante aparece en aquellos pacientes que han sufrido ablaciones más profundas.

In the alternative versions of both [22] and [23], a reporting verb is not necessary.

\section{Summary and conclusions}

The discussion and illustration of a wide range of instances of the verb 'report' in the contextual analysis have shown that the lexical choices and strategic options depend on the communicative setting and the linguistic environment. 
TABLE 2

Summary of translation options for the verb 'report' according to the communicative and linguistic setting

\begin{tabular}{|c|c|c|c|c|}
\hline \multicolumn{2}{|l|}{ Setting } & $\begin{array}{l}\text { Typical } \\
\text { Selections }\end{array}$ & $\begin{array}{l}\text { Alternative } \\
\text { Choices }\end{array}$ & $\begin{array}{l}\text { Occasional } \\
\text { Options }\end{array}$ \\
\hline \multicolumn{2}{|c|}{ Institutional } & Notificar & Declarar & $\begin{array}{l}\text { Referir } \\
\text { Registrar }\end{array}$ \\
\hline \multicolumn{2}{|c|}{ Community and Patient } & Referir & $\begin{array}{l}\text { Afirmar } \\
\text { Señalar }\end{array}$ & $\begin{array}{l}\text { Declarar } \\
\text { Indicar }\end{array}$ \\
\hline \multicolumn{2}{|c|}{ Current Study } & Presentar & Describir & $\begin{array}{l}\text { Aportar } \\
\text { Exponer }\end{array}$ \\
\hline \multicolumn{2}{|c|}{ Current Authors' Previous Research } & Describir & Publicar & $\begin{array}{l}\text { Señalar } \\
\text { Presentar }\end{array}$ \\
\hline \multirow{4}{*}{$\begin{array}{l}\text { Other } \\
\text { Authors' } \\
\text { Published } \\
\text { Work }\end{array}$} & 'As' clauses & Señalar & Reseñar & Referir \\
\hline & Infinitive Structure & Señalar & Describir & Comunicar \\
\hline & $\begin{array}{l}\text { Adjectival Function + } \\
\text { Passive Structure }\end{array}$ & $\begin{array}{l}\text { Publicar } \\
\text { Describir }\end{array}$ & $\begin{array}{l}\text { Comunicar } \\
\text { Referir }\end{array}$ & $\begin{array}{l}\text { Señalar } \\
\text { Recoger }\end{array}$ \\
\hline & Named Researcher & $\begin{array}{l}\text { Describir } \\
\text { Referir }\end{array}$ & $\begin{array}{l}\text { Publicar }{ }^{*} \\
\text { Señalar }\end{array}$ & $\begin{array}{l}\text { Comunicar } \\
\text { Encontrar } \\
\text { Observar }\end{array}$ \\
\hline
\end{tabular}

* Particularly indicated when the named researcher is agent in the passive

Table 2 summarizes the translation potential of most of the verbs discussed and for each category offers the typical lexical selection, together with less frequent alternative choices and appropriate but only occasional options. The adjectival function and passive structure categories have been conflated because of their great similarity in terms of lexical selection. The only category not included is that of anthropomorphic metonymy, where one of the strategies proposed in section 4.3.3. should be applied and this will clearly affect lexical choice. In any case, the table provides only an orientation in terms of typicality and the definitive selection will be conditioned by the other local factors mentioned in the discussion such as collocation, sentence structure or specific features of the communicative situation.

This study has shown that the choices made by translators of RAs often differ considerably from those made by native Spanish authors. Contextual analysis based on extensive corpora is a valuable research tool that can provide translators with quantitative and qualitative information to help them make appropriate choices for polysemous lexical items like 'report.'

\section{NOTES}

1. If lexical uses of the verbs 'be' and 'have' are excluded, 'report,' with its 210 instances, was the sixth most frequent lexical verb in the corpus after 'use' (414), 'show' (299), 'compare' (266), 'include' (231) and 'perform' (217).

2. The examples show the English original followed by the published translation (indicated by the arrow) and in some cases by a proposed alternative version (indicated by an asterisk). The lexical elements representing 'report' are shown in bold and other details of interest are signalled by underlining or as indicated in the text.

3. In Spain, when the newborn is normal, the birth can be reported to a registry fairly informally by telephone, as well as by letter; however, if a malformation is present or in cases of fetal death, the doctor has to make out and sign a formal document including his collegiate number. In the first 
setting, either notificar or declarar is appropriate but, in the second, declarar is indicated, as in 'reportable/notifiable disease' enfermedad de declaración obligatoria.

4. In a different setting, 'reporting bias' refers to the tendency for research that is financially supported by commercial interests to produce more favorable results than independent investigations; the Spanish equivalent for this phenomenon is sesgo de publicación.

\section{REFERENCES}

Halliday, M. A. K. (1985): An Introduction to Functional Grammar, London, Edward Arnold.

Navarro, F. A. (2000): Diccionario crítico de dudas inglés-español de medicina, Madrid, McGraw-Hill.

Scoтt, M. (1997): Wordsmith Tools, <http://liv.ac.uk/ ms2928/>. accessed on $10^{\text {th }}$ December, 2008.

Swales, J. (1990): Genre Analysis: English in Academic and Research Settings, Cambridge, Cambridge University Press.

Williams, I. A. (1994): "Contrastive analysis of finite verb profiles in 2 medical texts translated from Spanish into English,” Babel 40-3, pp. 146-169.

Williams, I. A. (2001): "Análisis de la estructura retórica de la introducción en artículos biomédicos: estudio contrastivo," in Moreno, A. I. y V. Colwell (eds.), Perspectivas recientes sobre el discurso, León, AESLA and Universidad de León, p. 178 and CD-ROM.

Williams, I. A. (2004): "How to manage patients in English-Spanish translation: A target-oriented contrastive approach to Methods," Target 16-1, pp. 69-103.

Williams, I. A. (2006): “Towards a target-oriented model for quantitative contrastive analysis in translation studies: An exploratory study of theme-rheme structure in Spanish-English biomedical research articles," Languages in Contrast 6-1, pp. 1-45.

Williams, I. A. (2007): "A corpus-based study of the verb observar in English-Spanish translations of biomedical research articles," Target 19-1, pp. 85-103.

Williams, I. A. (2008): "Semantico-syntactic environments of the verbs show and demonstrate and the Spanish mostrar and demostrar in a bilingual corpus of medical research articles," International Journal of Corpus Linguisticst 13-1, pp. 38-74. 